\title{
Sustainable mobility in the city of Larissa
}

\author{
S. Gerasimou \\ Department of Humanities, Social Sciences and Law, \\ Faculty of Applied Mathematics and Physics, \\ National Technical University of Athens, Greece
}

\begin{abstract}
According to Aristotle, the most beautiful city is the one that reaches harmony, which is the equilibrium between its population and size. This is a prerequisite for producing beauty within the city. Nowadays, the aforementioned proposal could be interpreted as a wide goal comprising contemporary principles aiming at preserving the quality of life, such as the protection of the environment, sustainability, sustainable development and sustainable mobility.

In this context, the paper examines sustainable mobility in Larissa, one of the major Greek cities in Thessaly. Larissa is a dynamic industrial, agricultural and cultural centre in the mainland of Greece with around 200.000 inhabitants. The first attempt to rationalize urban planning according to contemporary principles dates back to the seventies. Since that period the city has known a high development rate, while a series of plans and studies have been elaborated and implemented aiming at sustainable development, urban renaissance and sustainable mobility in the city centre. Thus, Larissa disposes of a wide pedestrian network as well as a less extended bike network. The above infrastructure connects the administrative centre to the traditional / old part of the city and finally to the river shores zone. The works in question have improved the quality of life and have had a direct positive impact on the physiognomy of the city. Therefore, the city could be considered as an interesting model case implementing sustainable mobility in Greece.

The paper presents the evolution and implementation of sustainable mobility in Larissa, showing off the institutional framework and taking into account the encountered difficulties. Finally, it concludes with proposals and perspectives of sustainable mobility and urban transport policy for the city in question, which could reveal a particular interest for towns of similar scale in the wider European area.
\end{abstract}

Keywords: urban transport, sustainable mobility, sustainable development, walk ability. 


\section{Introduction}

The city is the main nuclear of social life which creates civilization and reflects the values and traditions of society. During the classical era, Greek philosophers had expressed their ideas on city planning, which reflected the ideals of democracy on urban space. According to Plato the ideal city should be built 10 miles from the shore on a rough soil with a rich inner land. The main characteristic of the city could be resumed in the prevalence of public interest on individual ones, while virtue was the most important value of living together [1]. Following the same ideas Aristotle supported that social life should be guided by the principles of justice and political virtue; therefore the city had to adopt a middle size in harmony with its population [2].

In contemporary western society, as transport activity - in particular road and air traffic - is increasing, one of the main targets of urban policies is sustainable mobility. Therefore, EU policy-makers are trying to rationalise transport activity and develop policies of sustainable mobility. The Commission has set out a strategy on sustainability in the transport sector in its 2001 White Paper on Transport Policy. The strategy focuses predominantly on balancing the different modes of transport and harmonising legislation within specific sectors, but also on enhancing transport safety [3].

In Greek legal order, sustainable mobility has been introduced by doctrine and jurisprudence as an element of the principle of sustainable development, which is even explicitly mentioned by the amended in 2001 Section 24 of the Constitution. One of the specific meanings given to sustainable development is the principle of sustainable urban environment, which aims at the following: 1 rationalizing town and physical planning; 2 stopping urban sprawl; 3 ensuring quality public realm; 4 promoting sustainable mobility in the city [4]. The latter target consists in reducing automobile use within the city, while encouraging environment friendly transport means and improving bicycling and walking facilities.

The last twenty years Greek authorities under the influence of European city policy and the environmental degradation of the main city centers have been orientated towards sustainable solutions in urban planning policies. The most successful example has been the Unification of Athens Archeological sites project which has led to the creation of a continuous fabric of public spaces, parks and facilities for culture and recreation incorporating and linking all the significant cultural landmarks of Athens including its principal monuments and archaeological sites. The success of this operation has been crucial to the promotion of sustainable mobility in other cities some of which, including Larissa, had already adopted measures towards that direction.

\section{The evolution of town planning in Larissa}

The city of Larissa, lies in Thessaly, in the centre of Greece $(350 \mathrm{~km}$ from Athens and $150 \mathrm{~km}$ from Thessalonica) is one of the first cities in Greece. It has got a rich history of more than 4 millennia. According to a myth, Larissa was 
built during the Pelasgic period by Larissos, the son of Pelasgos. Since the 6th century BC it had become the seat of the Confederation of the Thessalians and reached its peak in the period 450-370 BC with a population of 100.000 inhabitants including the ones living in the outskirts outside the walls. During the same period used to take place horse-races of pan-Hellenic scale and radiance, "the horse ridden Thessalian Argos". From 433 to 195 BC under the influence of the Macedonians the city played a leading part in empowering Philip in his struggle for the Unification of the Hellenic element. In the Roman period it became the centre of Pompeius during the Roman civil war, while at the time of August it was a renowned Letters and Art centre.

In ancient times the city had a stadium, a musical academy, a theatre made of marble, many temples and a sewage system with built-in main pipes covered by clay plaques, as well as a central and a peripheral street system. Both the sewage and the street system were organised around the Agora (the centre of the Central Square).

During the late Roman and Byzantine periods the city prospered although barbaric hordes crossed its land (Goths, Visigoths, Normans and Francs). In 1423 the city surrendered to the Turks, who dominated it for more than four centuries. In the $17^{\text {th }}$ century Larissa according to the French priest Robert de Dreux, who accompanied the sultan and the French ambassador, and the English doctor Brown Larissa was a widespread commercial centre but so badly built, that it gave the impression of a village rather than a city. Most of the houses were one-storey and made of bricks. It was inhabited by Christians, Muslims and Jews. When the sultan decided to stay there in 1673 he had to build a wooden palace and the city was transformed into a cosmopolitan centre.

In 1881 the city was annexed to the contemporary Greek State which used town planning as a tool in order to impose national sovereignty and Europeanise the structure of the city. Two years later, in 1883, the first town plan of Larissa was elaborated regulating the development of a 20.000 residents' city [5]. The plan was inspired by both neoclassicism and the Hippodamus principles of rationalised town planning. It abrogated the irregular aspect of the urban tissue and provided for public realm and strait streets of a certain breadth. Furthermore, the plan respected private ownership as far as possible. Hence the society of Larissa embraced the innovative town plan until 1920. Since then the implementation rate of the plan has dramatically decreased due to the increasing shelter demand subsequent to the defeat of the Greek army in Asia Minor in 1922, to World War II and the civil war [6]. The town plan of Larissa has been revised several times $(1926,1938,1948,1956,1960,1962,1965,1968,1970$ 1976), for urban sprawl called for further expansions and the definition of special land uses (churches, prisons, schools, hospital, workers' residents).

In the late $20^{\text {th }}$ century, Larissa became one of the most dynamic cities of the country due to its location and the connection of its economy to the agricultural production of the surrounding area. Moreover, it had evolved into an industrial, administrative and cultural centre as well as a hub of the transport network of central Greece. However, this rapid growth was followed by unregulated development as occurred in most Greek cities. In the eighties the city reached a 
crucial point, since its physiognomy had been considerably altered; therefore local public opinion was ready to consider a different way of development. Hence, a policy of rationalized town planning and regeneration of the city centre was advocated.

The Master Plan of the city 1978/1980 set general principles for the operation of the city, while in 1986 was elaborated the General Town Plan of Larissa. After the approval of the Regional Land plan of Thessaly and the evolution of the national legal framework in the field, it was blatantly clear that the aforementioned plans should be revised. So, a new Master Plan and a new General Town Plan are being currently elaborated, given that the population of the city has reached near 200.000 inhabitants in an area of around 19.000 quarter acres.

\section{Sustainable mobility: a major target of urban renaissance in Larissa city centre}

The urban renaissance of the city centre was included in the General Town Plan of Larissa. Among the goals of the project figured: 1 upgrading the quality of life; 2 revitalizing the central area; 3 sustainable transport; 4 showing off the historical identity of the city and its physiognomy.

Hence, a series of studies and research projects have been conducted: "upgrading and revitalization of the historic town centre and the wider area of Pineos river" (1988), "general traffic and transport study" (1988), "updated study for the traffic signaling system" (1990) and "bikeway network study".

In 1985, despite the intense reactions of the inhabitants, the municipality of Larissa proceeded with the construction of the first parts of a pedestrian streets network of $1650 \mathrm{~m}$. length in the town centre aiming at enhancing the built environment. Soon the benefits in terms of profit for shopkeepers reversed the skeptical public opinion and the local society embraced the project.

According to the final proposal the pedestrian streets network should connect the commercial and administrative town district with historical sites, e.g. the castle and the ancient theatre, the river coast hosting sports facilities, the three main squares, the railway and the coach station as well as neighborhoods. Thus, the above project conceived the town as an operational and connective whole associating diversity and cultural development with compactness and mixed uses.

By 2005 the realized pedestrian network included around 200 quarter acres of the city centre comprising 25 blocks, the three main squares and approximately 8 $\mathrm{km}$ of pedestrian streets. Only one road crosses the above pedestrian district. Moreover, four car parks were created in municipal property, while two other municipal underground car parks were under construction.

Besides, the renaissance project provided for the creation of a bikeway network. Around $15 \mathrm{~km}$ have already been realized serving mainly schools, the archeological sites and the river coast. The future expansion of this network is estimated to include 54 more $\mathrm{km}$ of bikeway. 
The renaissance project apart from implementing sustainable mobility aimed at enhancing esthetics and the cultural heritage of the city. Thus, the three main squares have been remodeled, hosting sculptured fountains, while many trees have been planted. But the major impact of the renaissance project on the cultural heritage of the city is the excavation of the ancient theatre and its incorporation into the pedestrian network connecting the city centre to the river coast.

Following the completion of the greatest part of the renaissance project the reaction of citizens could be considered as positive. Permanent residents in the pedestrian network were satisfied because of both the reduction of noise and pollution and of the expanded public realm in front of their buildings. Shopkeepers have also seen a clear increase in their turnover.

Besides, walking around the city centre is now a pleasant stroll for permanent residents and visitors. Finally, the driver's attitude has changed, since they prefer either to go on foot for short distances or to choose alternative longer roots avoiding traffic congestion [7].

\section{Conclusions}

Urban renaissance of Larissa centre has considerably enhanced the physiognomy of the city. The pedestrian network has improved the built environment and public realm, reduced pollution and banned cars from the city centre. Moreover, this project was followed by the creation of a commercial, recreational and cultural zone with mixed uses, shaping the inhabitant's perception of the city as well as their social behavior. Moreover, the case of Larissa centre should be considered as a useful example of associating sustainable mobility with the protection of cultural heritage. In fact implementing sustainable mobility orientated the local public authorities and opinion towards the restoration and the connection of the city monuments to the urban tissue. The restoration of the castle, the urban renaissance of the old town around it and mainly the completion of the excavation works of the main part of the ancient theatre were the outcome of the will to create a pedestrian network in the city centre and finally a major part of the renaissance project.

The final result is in conformity with the main guidelines of sustainable mobility. Besides, it has played a key role in various projects promoting sustainable mobility in several cities in Greece, inspiring analogous interventions in other main cities of Thessaly, such as Trikala and Karditsa.

The main problems are insufficient policing of the pedestrian network and the multiplication of restaurants, cafes and bars. Hence, the city is facing unregulated parking, while the goal of mixed uses is being threatened [8].

Finally, the project of implementing sustainable mobility in Larissa has demonstrated that the success of any similar intervention depends highly on both the acceptance and participation of users and its incorporation in town and physical planning policies of wider geographical units. Therefore, special rules should apply, widening civil participation as well as environmental education, while the administrative procedure for the approval of these interventions needs 
to be simple and flexible within the limits set out by the European legal framework, the Constitution and jurisprudence.

\section{References}

[1] Hatzopoulou, A., The influence of legal rules on built environment and the physiognomy of the city, Archailogia, 79, pp. 69-72, 2001.

[2] Aristotle, Apanta, book 2, ed. Cactos: Athens, pp. 53, 69, 1993.

[3] EU News, Policy Positions \& EU Actors Online, 19 February 2006 www.SustainableMobility/EuropeanUnion/Transport.htm.

[4] Dekleris, M., Twelve rules for the environment, ed. A. N. Sakkoulas: Athens, 1995.

[5] Tloupas, T., Larissa-Images from the Past, ed. Ella: Larissa, pp. 14-21, 2003.

[6] Mihos, V. N., Neoclassicism in urban interventions in Larissa, Neoclassicism in Thessaly in the mid $19^{\text {th }}$ century-19, ed. Ministry of Culture, Larissa Folklore Museum: Larissa, pp. 55-63, 2005.

[7] Tzanakoulis, K., Mayor of Larissa, Initiatives and Perspectives - The example of Larissa, Proc of the $2^{\text {nd }}$ Pan-Hellenic Conference on Greek cities network over sustainable mobility and bicycle: Larissa, 2005.

[8] Aivaliotou, A., Technical Service Manager, Personal communication, 26 November 2005, Municipality of Larissa, Larissa, Greece. 